\title{
THE ART OF BEING NEGATIVE: METONYMICAL MORPHOLOGICAL CONSTRUCTIONS IN CONTRAST
}

\author{
TORE NESSET \\ University of Tromsø
}

\section{ABS TRACT}

This paper explores the metonymic nature of grammar by contrasting a Russian and a Norwegian morphological construction that give (mostly) negative characterizations of people. The meanings of the constructions are strikingly similar, and it is argued that they cannot be properly understood without recourse to metonymy. However, while Norwegian employs compounding, the morphological strategy used in the Russian construction is derivation. It is demonstrated that these differences are not idiosyncratic facts about Norwegian and Russian, since there is systemic motivation for the differences between the two languages.

\section{[1] INTRODUCTION}

Consider the following example from Ljudmila Ulickaja's short novel (повесть) Sonečka which contains the common gender noun зануда: ${ }^{1}$

(1) Таня назвала его занудой.

'Tanja called him a bore.'

In the Norwegian translation by Marit Bjerkeng, the word for 'bore' is rendered as the compound tørrpinn (lit. 'dry stick'):

(2) Tanja kalte ham en tørrpinn

'Tanja called him a bore.'

The observation that forms the starting point for the present study is that the translation of a Russian common gender noun in - $a$ by means of a compound in Norwegian is not a coincidence. In fact, there are numerous word pairs like зануда-tørrpinn, some of which are given in Table 1 on the following page. All the words in the table are negative characterizations of people, but they are morphologically different. The Russian words are examples of derivational morphology,

[1] Examples (1) and (2) are from the RuN corpus available at http://www.hf .uio.no/tekstlab/. 


\begin{tabular}{lll}
\hline Russian & Norwegian & English gloss \\
\hline жадоба, жад(н)юга & gjerrigknark & skinflint \\
плакса & tutemikkel & crybaby \\
сластёна & slikk(e)munn & person with sweet tooth \\
зубрила & pugghest & rote-learner \\
трусишка & reddhare & scaredy-cat \\
зануда & tørrpinn & bore,tedious person \\
злюка & sinnatagg & cross-patch \\
\hline
\end{tabular}

TABLE 1: Examples of the Russian Characteristic Derivation Construction and the Norwegian Characteristic Compound Construction

while the Norwegians are compounds. Accordingly, I will talk about two morphological constructions: the "Russian Characteristic Derivation Construction" and the "Norwegian Characteristic Compound Construction". I use the term "construction" about conventionalized pairings of form and function (Goldberg 2006, 3; see also Goldberg 1995 as well as Booij 2005 and 2009, who relates the term to morphology).

In my contrastive analysis of the two constructions, I will focus on the similarity of meaning, as well as the difference in form. In sections [2] through [4], it will be argued that metonymy is pervasive in the meaning of the constructions. Section [5] investigates the negative aspect of the meaning of the constructions, arguing that it arises as the result of the interplay of quantity and quality. In section [6], we turn to form. I propose that the fact that Russian uses a derivational pattern receives systemic motivation from the presence of hypocoristic wordformation and the role of the $a$-declension as a repository for marked persons in Russian. The contribution of the article is summed up in section [7].

\section{[2] METONYMY}

In the present study, I will use the term "metonymy" as it is used in contemporary cognitive linguistics:

(3) Metonymy is a cognitive process in which one conceptual entity, the vehicle, provides mental access to another conceptual entity, the target, within the same cognitive model (Radden \& Kövecses 1999, 21, see also Padučeva 2004, 157f., and Peirsman \& Geeraerts 2006).

Two aspects of this definition deserve mention. First, metonymy is not defined as a trope that is used to embellish poetry, nor is it described as a meaning shift occurring when one word is substituted for another. Rather, metonymy is first 
and foremost understood as a cognitive phenomenon that informs the way we think, act and speak. In Lakoff \& Johnson's $(1980,35)$ example the ham sandwich is waiting for his check, the ham sandwich is used to refer to a person. This person (the target) is accessed through the sandwich he has ordered (the vehicle), which is a salient property in the restaurant setting. The pervasiveness of examples like this in everyday speech suggests that the ability to perform metonymies is a fundamental property of human cognition.

The second part of the definition that calls for comment is the notion cognitive model. Alternative notions used in the definition of metonymy include domain (Kövecses 2002) and domain matrix Croft (2002). Peirsman \& Geeraerts (2006) criticize these notions as vague, and suggest instead a more traditional definition in terms of contiguity. Interesting as this discussion is, it does not have consequences for the present study, and it is therefore not necessary to go into further detail. Under all these approaches, the vehicle and target are closely related in space and/or time. For instance, in the ham sandwich example the sandwich and the person who ordered it are in the same restaurant at the same time. Without this close relationship, the metonymy could not arise. ${ }^{2}$

In recent years, metonymy has attracted considerable attention in cognitive linguistics. Benczes (2006) has emphasized the relevance of metonymy for compounding, and Janda (this volume) explores metonymy in derivational morphology. Langacker $(2009,46)$ goes as far as to say that "[g]rammar is basically metonymic". This claim will receive further support in the present paper, insofar as the morphological constructions under scrutiny cannot be understood without recourse to metonymy.

\section{[3] A GENERAL SCHEMA FOR THE MORPHOLOGICAL CONSTRUCTIONS}

In order to investigate the Russian Characteristic Derivation Construction and the Norwegian Characteristic Compound Construction I set up a database for each of them. The Russian database contains 369 nouns, which are all the nouns of common gender attested in Zaliznjak (1977). Common gender indicates that the nouns in question combine with masculine or feminine agreement targets depending on the biological sex of the referent. The Norwegian database, which comprises 523 compounds, was compiled from the electronic versions of Norsk riksmålsordbok (www.ordnett.no), and Bokmålsordboka and Nynorskordboka (www.dokpro.uio.no). Since dictionaries are often somewhat conservative when it comes to e.g. taboo

[2] Notice that once a metonymy has been created it can be used outside the setting where it arose. For instance, if a regular customer always order a ham sandwich at a certain restaurant, a waiter might well refer to the customer metonymically as the ham sandwich, even if s/he runs into the customer at a different location. 
words, a few words attested in Google searches are included in the database. ${ }^{3}$

The analysis of the two databases shows that the meaning of both constructions can be represented as follows:

(4) The nouns under scrutiny denote a PERSON who has a PROPERTY that is CHARACTERISTIC of the person and (often) NEGATIVE.

Let us return to the word pair зануда-tørrpinn 'bore' mentioned in the beginning of this study. Both words denote a person who is the carrier of the property of being boring, so in this sense they are arguments to the predicate 'be boring'. Being boring, furthermore, is characteristic of the person in question, and being boring is generally considered a bad thing. It should be pointed out that the description in (4) does not fit all the words in the database equally well. Although the vast majority of Russian common gender nouns denote persons, there are a few animals in the class (e.g. сивка 'dark gray horse', серка 'gray horse (or cat or $\left.\operatorname{dog})^{\prime}\right)$. Among the nouns denoting persons there is a small group of neutral terms (both Church Slavic words like nредтеча 'forerunner' and more recent borrowings like коллега 'colleague'). Moreover, some words involve positive evaluation (e.g. умница 'smart person'). However, the majority of the personal nouns involve negative characteristics. Since - as we will see in section [5] - negative evaluation is a matter of degree, it is not possible draw a clear-cut demarcation line between negative and non-negative nouns. A case in point is Norwegian driblefant '(excessive) dribbler'. There is nothing wrong with dribbling per se, but in excessive quantities it becomes a problem. The word is attested in clearly derogatory contexts, such as in a song by the Norwegian rock singer Åge Aleksandersen, where driblefant is used together with the clearly derogatory rotsekk 'slob' to characterize a bad soccer player. However, in recent newspaper prose the same word is sometimes used in a more neutral way to characterize technically skilled soccer players. In the following sentence, for instance, the emphasis is on the high market value of the player in question:

(5) Lyns driblefant har tiltrukket seg massiv oppmerksomhet fra interesserte klubber, men hittil har kun Brann avslørt sin interesse.

(Dagbladet, August 19 2009)

'Lyn's [name of Norwegian football club] dribbler has attracted massive attention from interested clubs, but so far only Brann [name of Norwegian football club] has made its interest public.'

[3] Since there is no grammatical marker that unites the class of compounds of interest in the present study, the Norwegian database could not be compiled fully automatically. A number of relevant second components (nouns denoting people, animals or body parts) were identified manually. Then electronic searches were performed in the dictionaries and all compounds ending in these nouns were identified. The compounds with relevant meaning were included in the database. I would like to express my gratitude to Maria Nordrum and Anna Baydimirova for their assistance with the databases. 
For the purposes of the present study, words like driblefant were included in the database, although they are not used exclusively as derogatory words.

In the beginning of this article, I emphasized the relevance of metonymy for the "Russian Characteristic Derivation Construction" and the "Norwegian Characteristic Compound Construction". We are now in a position to see why. In both constructions we access a person through a salient characteristic, such as tediousness or his/her inclination to perform excessive dribbling. This is a classic example of metonymy, which can be represented as CHARACTERISTIC FOR PERSON. In the terminology of Radden \& Kövecses' definition in (3), the characteristic property is the vehicle and the person the target. Both зануда-tørrpinn are related to adjectives (занудныц 'tiresome' and tørr 'dry'), but there are also words based on verbs and nouns in the databases. Examples of verb-based words are driblefant 'excessive dribbler' (cf. drible '(to) dribble') and moponbiza 'person always in a hurry' (cf. moponumbcr '(to) hurry'). Noun-based words include løgnhals 'liar' (lit. 'lie-throat') and сластёна 'person with sweet tooth'. In the case of noun-based words, we are arguably dealing with double metonymy. In løgnhals, for instance, the noun løgn 'lie' metonymically stands for the predicate of telling lies (RESULT FOR PROCESS), which in turn stands for the agent of this predicate, i. e. the teller of lies (AGENT FOR PROCESS). Similarly, in сластёна there is arguably a chain of metonymies from the object sweets to eating sweets, and then to the eater of sweets. ${ }^{4}$ What these examples show is that metonymy facilitates a precise description of the meaning of the constructions in Russian and Norwegian. In the following section, we will consider additional evidence for the pervasiveness of metonymy.

\section{[4] MORE METONYMY: NORWEGIAN COMPOUNDS}

In the Russian Characteristic Derivation Construction the person in question is represented in a highly schematic way. In words like moponblza 'person always in a hurry', the derivational suffix -iga indicates that we are dealing with a person who is negatively evaluated, but beyond that the suffix does not give us any information about the person in question. Cases like зануда 'boring person' are even less informative, since they do not involve an overt suffix at all. Here, language users have to have knowledge about the construction in order to be able to use and interpret the word correctly; if you know that Russian has a construction of deadjectival nouns in the - $a$ declension denoting persons, you may be able to tackle words like зануда even if the information you have is not sufficient to predict the exact meaning and use of the words in question.

The Norwegian Characteristic Compound Construction is in a sense more informative, insofar as compounds contribute two lexical roots. However, although

[4] From a synchronic point of view, I assume that сластёна is more closely related to the noun сласти 'sweets' than to the adjective сладкий 'sweet'. 
the second component of the compounds involves relevant information for the interpretation of the words, the interpretation is not straightforward, insofar as it requires cognitive processes such as metonymy. The compounds in my database can be divided into five types according to the meaning of the second component:

(6) Types of second components in Norwegian compounds:

a. Person: klossmajor 'clumsy person' (lit. 'clumsy major'), driblefant 'excessive dribbler' (lit. 'dribble-hobo')

b. Body part: kjøtthue 'meathead', løgnhals 'liar' (lit. 'lie-throat')

c. Animal: pugghest 'rote-learner' (lit. 'rote-learning horse'), stabukk 'stubborn old mule' (lit. 'stubborn billy-goat')

d. Object: tørrpinn 'bore' (lit. 'dry stick'), skravlebøtte 'chatterbox' (lit. 'chatterbucket')

e. Opaque: stabeis 'stubborn person' (beis is attested in the meaning 'paint', but that seems irrelevant for the synchronic analysis of stabeis).

In the following, we shall take a closer look at types (6a) and (6b), which shed light on one of the main topics of this study, namely metonymy. In compounds like klossmajor 'clumsy person' and driblefant 'excessive dribbler', the second component denotes a person with specific characteristics. The noun major 'major' describes a person with a military rank between captain and lieutenant-colonel. If the compound klossmajor were fully compositional, one would therefore expect the meaning to be 'clumsy major'. However, it is not. You do not have to graduate from a military academy in order to be a klossmajor - the compound denotes any clumsy person. The word fant 'hobo' denotes a person who belongs to a particular social group. However, you don't have to be a hobo in order to classify as a driblefant. Any person, regardless of his/her social background can be a driblefant as long as s/he dribbles a lot. In fact, since hobos generally are not involved in soccer and similar sports, it would be extremely unlikely that one would be able to find a single instance of a hobo who could be characterized as a driblefant. What we see in cases like klossmajor and driblefant, is that a specific person (an army officer or a hobo) stands for a person in general. Since major and hobo are hyponyms of person, this can be analyzed as the metonymy HYPONYM FOR HYPERNYM (Peirsman \& Geeraerts 2006, 277 and 306-408, see also Dirven 1998, 284 for discussion of similar metonymies in noun-verb conversion). In order to interpret Norwegian compounds where the second component denotes a person, language users have to perform a metonymy. If we imagine a language user who for some reason cannot handle metonymies, $\mathrm{s} / \mathrm{he}$ would be at loss when facing compounds like klossmajor and driblefant.

Compounds where the second component is a body part also presuppose metonymy. If the meaning of kjøtthue 'meathead' and løgnhals 'liar' were fully com- 
positional, these words would denote a head and a throat, respectively, since hue means 'head' and hals 'throat'. However, the words denote people, so in order to interpret such compounds language users have to perform a metonymy from a body part to the person with this body parts. In other words, a body part stands for a person. This is an example of the PART FOR WHOLE metonymy - one of the most studied examples of metonymy, known as pars pro toto in classical rhetoric. Peirsman \& Geeraerts $(2006,309)$ regard part-whole relations as the prototypical type of metonymy.

At this point the question arises as to how speakers are able to identify the meaning of compounds like kjøtthue and løgnhals. How do language users know that they have to perform a metonymy? Why don't they misunderstand? Why don't people think that these words denote body parts? I have no pretensions of giving a complete answer to these questions, but the facts about the Norwegian Characteristic Compound Construction shed light on three of the factors involved: context, entrenchment and blocking. Words occur in a context, which often gives the language user hints as to whether a metonymy should be performed or not. If I say Jon er et kjøtthue 'John is a meathead', the context prompts a metonymical reading since Jon is most likely the name of a person, and not of a head. However, context is not always enough. If you hear me say For et kjøtthue! 'What a meathead!' the (immediate) context does not necessarily exclude reference to a head with a surprisingly large amount of meat on it.

Another observation is that not any body part will do in the construction. The distribution of body parts is clearly skewed in my data. As shown in Table 1 on page 262 and Figure 1 on page 269, there is a strong tendency for the nouns in question to involve the head or some part of it, such as the mouth. Taken together, the head and the throat (which is arguably part of the head) account for $77 \%$ of the body part compounds in my database. I suggest that language users can utilize this fact. If s/he encounters a compound involving the head, s/he can with some degree of confidence, at least, infer that the compound is used metonymically for the person as a whole. If, on the other hand, a language user comes across an unfamiliar compound involving, say, the heart, s/he would have a much weaker basis for performing the metonymy from body part to person. The Norwegian word for 'heart', hjerte, forms numerous compounds, but these compounds do not stand metonymically for persons. A case in point is vennehjerte 'friend's heart', which according to Norsk Riksmålsordbok can be used metaphorically to refer to a friend's warm feelings, but cannot be used metonymically to refer to the person who has these feelings. Another example is sovehjerte (lit. 'sleep-heart'), which denotes the ability to fall asleep easily, not the person who has this ability. 


\begin{tabular}{|c|c|c|c|}
\hline Body part & $\begin{array}{l}\text { Raw } \\
\text { frequency }\end{array}$ & Per cent & Examples \\
\hline Head/part of head & 37 & 60.7 & $\begin{array}{l}\text { kjøtthue 'meathead', slikk(e)munn } \\
\text { 'person with sweet tooth' (lit. } \\
\text { 'lick-mouth') }\end{array}$ \\
\hline Throat & 10 & 16.4 & $\begin{array}{l}\text { løgnhals 'liar' (lit. 'lie-throat'), } \\
\text { skrikhals 'cry-baby' (lit. 'scream- } \\
\text { throat') }\end{array}$ \\
\hline Genitals & 9 & 14.8 & $\begin{array}{l}\text { hestkuk 'asshole' (lit. 'horse- } \\
\text { penis'), dovenpeis 'lazybones' (lit. } \\
\text { 'lazy penis') }{ }^{5}\end{array}$ \\
\hline Torso & 2 & 3.3 & $\begin{array}{l}\text { dovenkropp 'lazybones' (lit. 'lazy } \\
\text { body'), urokropp 'live wire' (lit. } \\
\text { 'unrest-body') }\end{array}$ \\
\hline Fur & 2 & 3.3 & $\begin{array}{l}\text { svinepels 'bastard' (lit. 'swine-fur'), } \\
\text { revepels 'smarty pants' (lit. 'fox- } \\
\text { fur') }\end{array}$ \\
\hline Hand & 1 & 1.6 & $\begin{array}{l}\text { treneve 'clumsy person' (lit. 'wood- } \\
\text { fist') }\end{array}$ \\
\hline Total & 61 & 100.1 & \\
\hline
\end{tabular}

TABLE 2: Distribution of body parts in the Norwegian Characteristic Compound Construction

I suggest that the effect described in the previous paragraph is an "entrenchment effect". The head is more frequently used in the construction, and therefore represents a more entrenched pattern in the terminology of Langacker $(1987,59$ and 2008, 16-17). The idea that language users utilize entrenchment for the interpretation of compounds is simple, but nevertheless has far-reaching implications for linguistic theory. The entrenchment effect suggests that the language faculty is not, or at least not only, an algorithm for manipulation of abstract symbols, but is sensitive to (type) frequency (for more about the relationship between frequency and linguistic structure, see Bybee 2001, 2007).

In addition to the context and entrenchment effects, I suggest that there is a blocking effect that helps the language users perform metonymies. Some of

[5] Compounds with peis as the second component are included in the category "genitals" since Norsk Riksmålsordbok defines peis as the "penis of an animal, especially a bull" (My translation, TN). However, apart from compounds, this word is not much used in contemporary Norwegian, and many speakers are probably not aware of its meaning. For such speakers, compounds in peis are of the opaque type in (6e). 


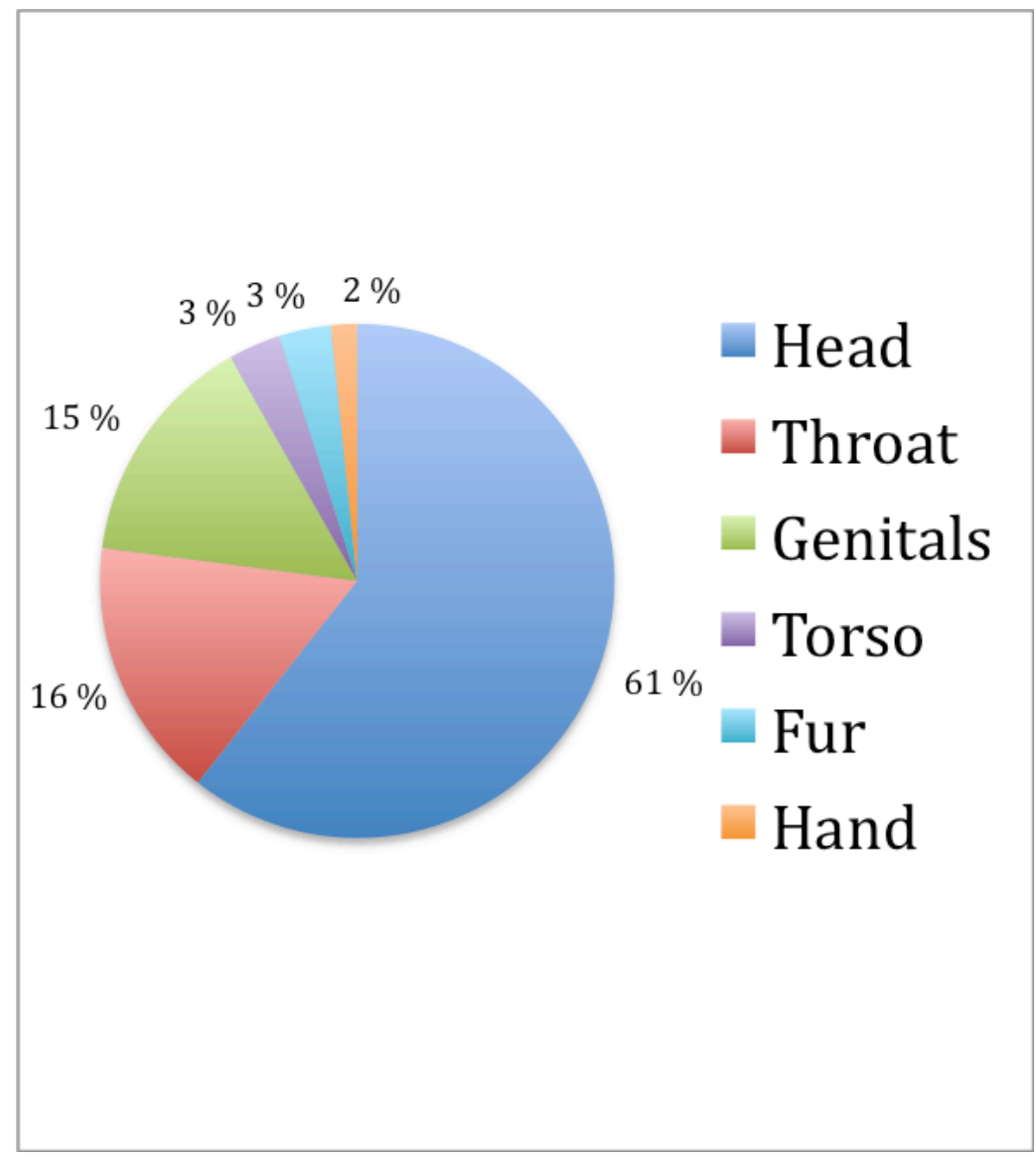

FIGURE 1: Distribution of body parts in the Norwegian Characteristic Compound Construction

the compounds in the database can be interpreted literally. As mentioned, kjøtthue 'meathead' might potentially be used to designate a head with a surprisingly large amount of meat on it. However, world knowledge tells us that this is not a very likely interpretation, since most of us do not encounter situations where the amount of meat on heads is so salient that we need a separate lexical item to refer to it. ${ }^{6}$ A word where a literal interpretation is more likely is revepels. This word can be used in the meaning 'smarty pants' (lit. 'fox-fur'), but it is equally natural to use the word to refer to the animal's fur or a coat made from the fur. In cases like slikk(e)munn 'person with a sweet tooth' (lit. 'lick-mouth'), however, a literal

[6] Notice that the (ir)relevance of the amount of meat on heads is culture specific. In cultures where animal heads are prepared for food, the amount of meat on a head may be crucial. An example that comes to mind is western Norway where the dish smalahove is prepared from the head of a sheep. 
interpretation is much less likely. World knowledge indicates that mouths cannot lick, at least not independently of the person who "owns" the mouth. Admittedly, one could perhaps conceive of using slikk(e)munn about a contraption with some similarity to a mouth, but this would be quite far-fetched. What I suggest is that when a literal interpretation is blocked, the language user is encouraged to perform a metonymy. A thorough discussion of blocking in morphology is beyond the scope of the present article, so the interested reader is referred to CarstairsMcCarthy (1992, 33f.), Haspelmath (2002, 108f. and 249f.) and Aronoff \& Fudeman $(2005,218 f$.$) and references therein. Notice, however, that the blocking effect is$ not an either-or matter, since a literal interpretation can be more or less likely. Once again, we are not dealing with an algorithmic system of strict rules. Rather, the human mind seems to be sensitive to various degrees of likelihood of a literal interpretation in the same way as it is sensitive to a pattern's degree of entrenchment.

In addition to illustrating the context, entrenchment and blocking effects, the data in Table 2 on page 268 and Figure 1 on the preceding page raise an important question: Why is the head so prevalent in the Norwegian Characteristic Compound Construction? Several factors deserve mention. First, in folk models the head is considered the home of the rational self, and it is therefore important in defining the personality, including negative characteristics. Second, the head is crucial for biological functions such as eating and social functions such as speech. Finally, as opposed to e.g. the heart, which is important in folk models as the home of emotions, the head is visible, and it is possible that visibility enhances the use of the head in metonymy. The common denominator for the three factors is salience - the head is salient in relevant folk models, biological and social functions and with regard to visibility. Salience is often regarded as a relevant factor in metonymy (see e.g. the discussion of reference point constructions in Langacker 2008, 83). This study of the Norwegian body part compounds lends support to this idea.

As shown in Table 2 and Figure 1, genitals (male and female) are relatively frequent in the Norwegian Characteristic Compound Construction. In my database, they represent $15 \%$ of the body part compounds. Once again, salience seems to be a key word, insofar as the genitals distinguish between males and females. Needless to say, natural gender is a salient property biologically and socially. In addition to this, however, many words for genitals are taboo words, which makes them particularly well suited in derogatory use. This takes us to an important question: what is negative? This is the topic of the next section.

\section{[5] What is NEGATIVE?}

As a first approximation to this question, we may look at (7) and (8), where I list a number of Norwegian and Russian words classified into various categories. 
(7) What is "bad" in Norwegian?

a. Immoral behavior: drinking (fyllefant 'drunkard'), lying (ljugarfant 'liar'), stealing (tjuvradd 'petty thief'), laziness (lathans 'lazybones'), adultery (horebukk 'lecher')

b. Annoying behavior: talking (skravlebøtte 'chatterbox'), teasing (ertekrok 'teaser')

c. Pointless, idle activity: pugghest 'rote-learner', driblefant 'excessive dribbler'

d. Physical characteristics: brillejesus 'four-eyes', halteper 'person who limps'

e. Marginal social groups: ferdafant 'tramp', byfant 'derogatory word for city dweller', bondeknøl 'country bumpkin', fattiglus 'pauper', svenskeradd 'derogatory word for Swede'

f. Stupidity/clumsiness: dustemikkel 'fool', dummepetter 'fool', klossmajor 'clumsy person'

g. Mentality: anger (sinnatagg 'cross-patch'), melancholy (tåreperse 'crybaby'), being difficult (vriompeis 'pighead'), dullness (tørrpinn 'bore')

h. Cowardice: reddhare 'scaredy-cat', knehøne 'coward'

i. Showing off: spradebasse 'peacock, dandy', flottenfeier 'poser'

j. Luck, smartness: heldiggris 'lucky dog'

(8) What is "bad" in Russian?

a. Immoral behavior: drinking (пьяница 'drunkard', гуляка 'boozer, idler'), lying (вруша 'liar', врунишка 'liar'), stealing (ворюга 'petty thief'), laziness (лежебока 'lazybones'), murder (убийца 'murderer')

b. Annoying behavior: talking (балаболка 'chatterbox', болтунишка 'chatterbox'), teasing (задира 'teaser')

c. Pointless, idle activity: зубрила 'rote-learner', мазила 'dauber', писака 'scribbler'

d. Physical characteristics: калека 'cripple', коротконожка'short-legged person'

e. Marginal social groups: бродяга 'tramp', бедняга 'poor fellow', немчура 'derogatory word for German'

f. Stupidity/clumsiness: дурында 'fool', недотёпа 'duffer', мямля 'mumbler'

g. Mentality: anger (злюка 'cross-patch'), melancholy (плакса 'crybaby', нюня 'crybaby'), being difficult (капризнюля 'capricious child'), dullness (зануда 'bore')

h. Cowardice: трусишка 'coward'

i. Showing off: задавака 'show off', ломака 'poser'

j. Luck, smartness: хитрюга 'sly, cunning person', пройда 'creeper' 
This classification is not exhaustive, but (7) and (8) suffice to illustrate two important points. First of all, the same categories recur in both Norwegian and Russian. The Norwegian Characteristic Compound Construction and the Russian Characteristic Derivation Construction therefore do not seem to provide fertile soil for linguists looking for national stereotypes. The second point is that there is no small and clearly delineated set of negative properties that occur in the constructions under scrutiny in this study. On the contrary, almost anything can be considered negative in one way or other. A word like хитрюга 'sly, cunning person' is a good example. While being smart or resourceful is a good thing per se, as suggested by the gloss, the word хитрюга is often used with negative connotations about people who are willing to manipulate others in order to achieve their goals:

$$
\begin{aligned}
& \text { Увидев, что Лева запросто перетаскивает пудовые узлы, хитрюга борт- } \\
& \text { механик сначала восхитился его силой, потом попросил передвинуть } \\
& \text { полтонны груза и спокойно смотрел, как Лева в одиночку делает его, } \\
& \text { бортмеханика, работу (V. Sanin 1987) } \\
& \text { 'Having seen that Leva was simply dragging packs of one pood [=16.3 kilos] } \\
& \text { in weight, the sly and cunning flight engineer admired his strength, and } \\
& \text { then asked him to move half a ton of cargo while calmly looking at Leva } \\
& \text { doing the flight engineer's job alone.' }
\end{aligned}
$$

For the purposes of the constructions we are interested in, things are not bad in themselves. Whether something is negative or not, depends on how a situation is construed. Construal, which has to do with the human capacity for adopting different perspectives, may be defined as the relationship between a conceptualizer and the conceptualization s/he entertains (Langacker 1987, 128, 1991, 546, 2008, 55ff.). According to Verhagen $(2007,48)$, construal involves "facets of meaning and grammatical organization which crucially make use of notions such as 'perspective', 'subjectivity', or 'point of view'. What these notions have in common is that they capture aspects of conceptualization that cannot be sufficiently analyzed in terms of properties of the object of conceptualization, but [...] necessarily involve a subject of conceptualization." Clearly, we cannot understand the words in (7) and (8) without taking construal into consideration.

What are the factors that underlie the construal of negative characteristics in the Norwegian and Russian morphological constructions? I suggest that both quality and quantity are important. As for quality, the overviews in (7) and (8) indicate that the adopted perspective is always that of a majority against outliers. If a person is characterized as fyllefant 'drunkard' or the corresponding Russian word пьяница, s/he shows behavior that is unacceptable from the perspective of the majority's norms. Exactly what is construed as sins and vices presumably

[7] Example from The Russian National Corpus available at http://www.ruscorpora.ru. 
varies among cultures and languages. As mentioned, the lists in (7) and (8) are remarkably similar, but since other cultures have other stereotypes, it is likely that morphological constructions in other languages reflect different construals. In any case, it is clear that the meaning of morphological constructions is deeply intertwined with cultural stereotypes. As Enfield $(2002,3)$ remarks, "[g]rammar is thick with cultural meaning".

Quantity is also a relevant factor. In section [3], I mentioned that dribbling in driblefant is not negative per se, but becomes problematic in excessive quantities. Similarly, words like skravlebøtte 'chatterbox' and its Russian equivalents балаболка and болтунишка involve excessive talking. Talking is not a bad thing in itself, but in large quantities it can become annoying, especially if there is not much content. These examples suggest that excessive quantity compensates for the lack of graveness of the relevant sin or vice. But there are also examples where it is sufficient to commit the sin only once and still be a full-fledged member of the category. Nouns like убийца 'murderer' and horebukk 'lecher' illustrate this. ${ }^{8}$ Here we are dealing with grave sins that the people in question may only have committed once. However, quality compensates for low quantity.

I depict the relationship between construal, quality and quantity informally in Figure 2 on the next page. Let the origin represent the observer, i.e. the perspective of the majority from which a situation is construed. The vertical axis captures the qualitative dimension, where a high value indicates that something is construed as highly negative. The horizontal axis represents the quantitative dimension, where a high value corresponds to excessive quantity. What can be called "acceptable behavior" is represented by a sector, while everything outside this sector is "bad". In order to be outside the sector, an action must be high with regard to quality or quantity (or both). Horebukk 'lecher' and убийua 'murderer' receive high values for bad quality, but not for excessive quantity, whereas skravlebøtte 'chatterbox' and балаболка 'chatterbox' score high for quantity, but not for bad quality. In other words, both quality and quantity contribute to the construal as negative, and a high value for one factor compensates for a low value for the other.

\section{[6] WHY DERIVATION IN RUSSIAN?}

In the beginning of this article, we saw that the Norwegian and Russian constructions are similar in meaning, but different in form. So far we have been concerned with meaning, but now we turn to form. Is it possible to explain the differences be-

[8] Not all native speakers of Norwegian share my intuition that horebukk can be used felicitously about a person who has committed the relevant sin only once. An (even) clearer example is hanrei 'cuckold, deceived husband' - it is enough to be deceived on one occasion to qualify as a full-fledged member of the category. Since the difference between horebukk and hanrei may reflect a higher tolerance for promiscuity for men in traditional culture, we are arguably dealing with an example of the lexicalization of sexist ideologies in language. 


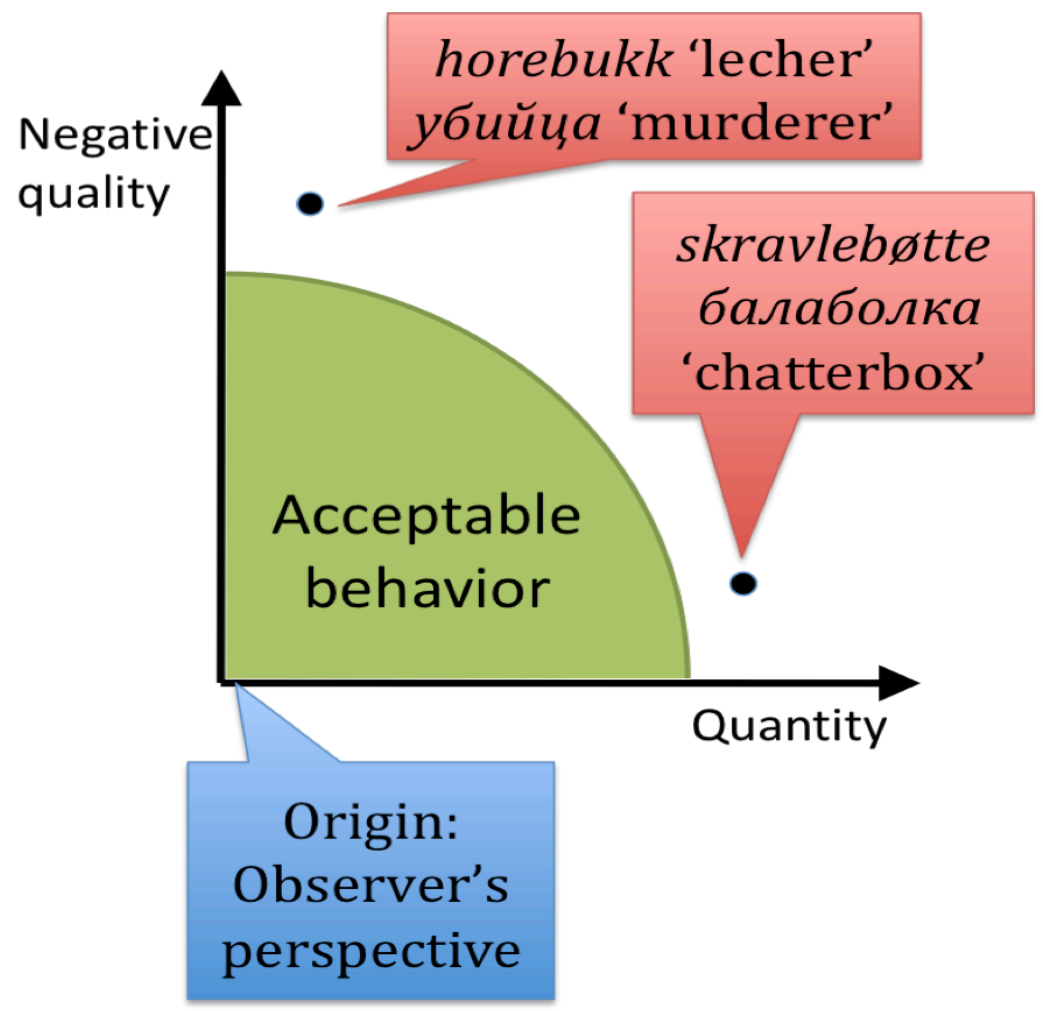

FIGURE 2: Construal, quality and quantity

tween the Norwegian and Russian constructions? And what exactly is it we need to explain? Is it the fact that Norwegian employs compounding that demands an explanation, or should we rather try to motivate the use of derivational morphology in Russian? Adopting a grammaticalization perspective, I suggest focusing on Russian. By grammaticalization, I mean the historical process whereby lexical morphemes develop into grammatical morphemes, i. e. affixes (Bybee et al. 1994, 4; Hopper \& Traugott 1993, 2). Derivation is further down the grammaticalization cline, since compounding is closer to the mere juxtaposition of two separate lexical items. The question is why Russian has proceeded further along the grammaticalization cline. In other words, we must ask whether there is systemic motivation in the Russian grammar for expressing negative characteristics by means of derivation.

A first observation is that Russian is heavily invested in derivation. As shown by Janda (this volume), Russian displays almost five times as many derivational suffixes as Norwegian (274 in Russian compared to 57 in Norwegian). Admittedly, Janda's analysis is concerned only with metonymical derivational patterns, but since she shows that metonymy is pervasive in derivation, it stands to reason that 
Janda's results are indicative of the word formation system as a whole.

A second observation is that Russian has a rich system of diminutive derivation, a feature that Norwegian word formation lacks. As is commonly observed, the most important function of Russian diminutive suffixes is not to indicate the small size of the referent, but rather to characterize the speaker's emotional relationship to the referent (see e. g. Townsend 1975; Wierzbicka 1992). If a speaker chooses the diminutive form злючка 'cross-patch' instead of the neutral злюка, this indicates that the speaker has a more emotional relationship to the person in question. In other words, diminutives incorporate a system of evaluation in Russian word formation. This provides systemic motivation for the Russian Characteristic Derivation Construction, which also expresses evaluation through derivational morphology.

A third point concerns the role of the a-declension in Russian. ${ }^{9}$ This inflection class comprises both inanimate and animate nouns. Among animates, those denoting persons are particularly relevant for our purposes. As pointed out in Nesset $(2001,201)$, the personal nouns in the $a$-declension largely fall into three categories: ${ }^{10}$

(10) Personal nouns in the $a$-declension:

a. Females (e.g. соседка 'female neighbor')

b. Hypocoristic forms of names (е.g. Ваня from Иван)

c. Characteristic nouns of common gender (e.g. плакса 'crybaby')

I suggest that the $a$-declension serves as a repository for marked persons in Russian morphology. Nouns denoting females are often morphologically marked in the sense that they are derived from nouns denoting males. For instance, соседка 'female neighbor' is derived from coced, which is used about male neighbors or neighbors in general. From the point of view of feminist theory, one can even argue that words for females are semantically marked, since traditional stereotypes tend to construe women as the "second sex" (de Beauvoir 1993, see also Nesset 2001 for extensive discussion summarized in Dirven et al. 2007, 1231-1232). The hypocoristic nouns in (10b) are semantically marked as well; such nouns are used when the speaker has a special, intimate relationship to the addressee. Finally, the common gender nouns investigated in the present study are marked in the sense that they tend to involve negative evaluation of the referent. In other words, all the groups in (10) involve marked persons. This shows that the fact

[9] I use the term " $a$-declension" to refer to the inflection class of nouns ending in $/ a /$ in the Nominative Singular. This class is called the "first declension" in the Russian tradition, but labeled the "second declension" in Western works on Russian grammar.

[10] In addition, there are kinship terms like nana 'daddy' that are related to the hypocoristic forms in (10b) and some masculine characteristic nouns (e.g. волокита 'skirtchaser') that resemble the common gender nouns in (10c). 
that the Russian Characteristic Derivation Construction involves nouns in the $a$ declension is not an arbitrary idiosyncrasy. On the contrary, the $a$-declension's function as a repository for marked persons in Russian provides systemic motivation for expressing negative evaluation through the Russian Characteristic Derivation Construction.

\section{[7] CONCLUSION}

The juxtaposition of the Norwegian Characteristic Compound Construction and the Russian Characteristic Derivation Construction has shown that they are different in form, but strikingly similar in meaning. Both morphological constructions give (mostly) negative characterizations of people, covering large, but very similar sets of sins and vices in both languages. We have seen that the two constructions cannot be properly understood without recourse to metonymy, and the proposed analysis therefore lends support to the idea that metonymy is pervasive in word formation and grammar in general. As for form, the Russian expression of negative characteristics through derivation receives systemic motivation from the language's rich system of diminutive derivation, as well as from the function of the $a$-declension as a repository of marked persons.

This study indicates that detailed contrastive analysis can shed light on the similarities and differences between Norwegian and Russian and identify properties that might have been overlooked in analyses of either language in isolation. But first and foremost this study illustrates how contrastive analysis informs linguistic theory - in our case by demonstrating the pervasiveness of metonymy in grammar.

\section{AC KNOWLEDGMENTS}

I would like to thank Hans-Olav Enger, Atle Grønn, Laura A. Janda and audiences in Oslo and Prague for comments on earlier versions of this article. Thanks also to my employer, the University of Troms $\varnothing$, and Sparebankens gavefond for financial support.

\section{REFERENCES}

Aronoff, Mark \& Kirsten Fudeman. 2005. What is morphology? Oxford: Blackwell.

de Beauvoir, Simone. 1993. The second sex. London: David Campbell.

Benczes, Réka. 2006. Creative compounding in English. Amsterdam, Philadelphia: John Benjamins.

Booij, Geert. 2005. Compounding and derivation: evidence for Construction Morphology. In Wolfgang U. Dressler, Francesco Gardani \& Markus A. Pöchtrager 
(eds.), Morphology and its demarcations: selected papers from the 11th morphology meeting, Vienna, February 2004, 109-132. Amsterdam, Philadelphia: John Benjamins.

Booij, Geert. 2009. Compounding and Construction Morphology. In Rochelle Lieber \& Pavol Štekauer (eds.), The Oxford handbook of compounding, 201-216. Oxford: Oxford University Press.

Bybee, Joan. 2001. Phonology and language use. Cambridge: Cambridge University Press.

Bybee, Joan. 2007. Frequency and the organization of language. Oxford: Oxford University Press.

Bybee, Joan, Revere Perkins \& William Pagliuca. 1994. The evolution of grammar. Chicago, London: The University of Chicago Press.

Carstairs-McCarthy, Andrew. 1992. Current morphology. London, New York: Routledge.

Croft, William. 2002. The role of domains in the interpretation of metaphors and metonymies. In René Dirven \& Ralf Pörings (eds.), Metaphor and metonymy in comparison and contrast, 161-205. Amsterdam, Philadelphia: John Benjamins.

Dirven, René. 1998. Conversion as a conceptual metonymy of event schemata. In Klaus-Uwe Panther \& Günter Radden (eds.), Metonymy in language and thought, 275-288. Amsterdam, Philadelphia: John Benjamins.

Dirven, René, Frank Polzenhagen \& Hans-Georg Wolf. 2007. Cognitive linguistics, ideology, and critical discourse analysis. In Dirk Geeraerts \& Hubert Cuyckens (eds.), The Oxford handbook of cognitive linguistics, 1222-1240. Oxford: Oxford University Press.

Enfield, Nick J. 2002. Ethnosyntax: Introduction. In Nick J. Enfield (ed.), Ethnosyntax: explorations in culture and grammar, 1-30. Oxford: Oxford University Press.

Goldberg, Adele E. 1995. Constructions. Chicago: The Chicago University Press.

Goldberg, Adele E. 2006. Constructions at work. Oxford: Oxford University Press.

Haspelmath, Martin. 2002. Understanding morphology. London: Arnold.

Hopper, Paul \& Elizabeth Traugott. 1993. Grammaticalization. Cambridge: Cambridge University Press. 
Hovdenak, Marit, Laurits Killingbergtrø, Arne Lauvhjell, Sigurd Nordlie, Magne Rommetveit \& Dagfinn Worren (eds.). 2001. Nynorskordboka. Oslo: Det Norske Samlaget. http://www.dokpro.uio.no.

Janda, Laura A. this volume. Russian word-formation in contrast with Czech and Norwegian.

Knudsen, Trygve, Alf Sommerfelt, K. Emil Bødtker \& Harald Noreng (eds.). 1937-1957. Norsk riksmålsordbok. Oslo: Aschehoug. http://www .ordnett.no.

Kövecses, Zóltan. 2002. Metaphor: a practical introduction. Oxford: Oxford University Press.

Lakoff, George \& Mark Johnson. 1980. Metaphors we live by. Chicago: The University of Chicago Press.

Landrø, Marit Ingebjørg \& Boye Wangensteen. 1986. Bokmålsordboka. Bergen, Oslo, Stavanger, Tromsø: Universitetsforlaget. http://www. dokpro.uio.no.

Langacker, Ronald W. 1987. Foundations of cognitive grammar, vol. 1. Stanford: Stanford University Press.

Langacker, Ronald W. 1991. Foundations of cognitive grammar, vol. 2. Stanford: Stanford University Press.

Langacker, Ronald W. 2008. Cognitive grammar: a basic introduction. Oxford: Oxford University Press.

Langacker, Ronald W. 2009. Metonymic grammar. In Karl-Uwe Panther, Linda L. Thornburg \& Antonio Barcelona (eds.), Metonymy and metaphor in grammar, 45-71. Amsterdam, Philadelphia: John Benjamins.

Nesset, Tore. 2001. How pervasive are sexist ideologies in grammar? In René Dirven, Bruce Hawkins \& Esra Sandikcioglu (eds.), Language and ideology. Volume I: Theoretical cognitive approaches, 197-226. Amsterdam, Philadelphia: John Benjamins.

Padučeva, Elena Viktorovna. 2004. Dinamičeskie modeliv semantike leksiki. Moscow: Jazyki slavjanskoj kul'tury.

Peirsman, Yves \& Dirk Geeraerts. 2006. Metonymy as a prototypical category. Cognitive Linguistics 17. 269-316.

Radden, Günter \& Zóltan Kövecses. 1999. Towards a theory of metonymy. In Karl-Uwe Panther (ed.), Metonymy in language and thought, 17-60. Amsterdam, Philadelphia: John Benjamins. 
Townsend, Charles E. 1975. Russian word-formation. Columbus, OH: Slavica Publishes.

Verhagen, Arie. 2007. Construal and perspectivization. In Dirk Geeraerts \& Hubert Cuyckens (eds.), The Oxford handbook of cognitive linguistics, 48-81. Oxford: Oxford University Press.

Wierzbicka, Anna. 1992. Semantics, culture and cognition. Oxford, New York: Oxford University Press.

Zaliznjak, Andrej Anatol'jevič. 1977. Grammatičeskij slovar' russkogo jazyka. Moscow: Russkij jazyk.

\author{
AUTHOR CONTACT INFORMATION \\ Tore Nesset \\ University of Tromsø \\ Department of Language and Linguistics \\ NO-9037 Tromsø \\ Norway \\ tore.nesset@uit.no
}

